Check for updates

Cite this: RSC Adv., 2018, 8, 12823

Received 21st February 2018

Accepted 19th March 2018

DOI: $10.1039 / c 8 r a 01571 f$

rsc.li/rsc-advances

\section{Totally room-temperature solution-processing method for fabricating flexible perovskite solar cells using an $\mathrm{Nb}_{2} \mathrm{O}_{5}-\mathrm{TiO}_{2}$ electron transport layer}

\author{
Jun Jiang, Shubo Wang, Xuguang Jia, (D) Xiang Fang, Shuai Zhang, Jing Zhang, \\ Wei Liu, Jianning Ding* and Ningyi Yuan (D)
}

\begin{abstract}
Flexible perovskite solar cells are new technology-based products developed by the global solar industry and are promising candidates for realizing a flexible and lightweight energy supply system for wearable and portable electronic devices. A critical issue for flexible perovskite solar cells is to achieve high power conversion efficiency (PCE) while using low-temperature solution-based technology for the fabrication of a compact charge collection layer. Herein, we innovatively introduce niobium ethoxide as a precursor additive to $\mathrm{TiO}_{2} \mathrm{NCs}$, which allows realization of an $\mathrm{Nb}_{2} \mathrm{O}_{5}-\mathrm{TiO}_{2}$ electron transport layer (ETL). The presence of $\mathrm{Nb}_{2} \mathrm{O}_{5}$ remarkably enhances electron mobility and electrical conductivity of the ETLs. In addition, uniform perovskite films are prepared by an annealing-free solution-based method. The excellent performance of the cell is attributed to its smooth film surface and high electron mobility, and performance is verified by the effective suppressions of charge recombination and time-resolved photoluminescence. PCEs of $15.25 \%$ and $13.60 \%$ were obtained for rigid substrates (glass/fluorine-doped tin oxide) and an indium tin oxide/PET (poly(ethylene terephthalate)) flexible substrate by using a totally room-temperature solution-processing method, respectively.
\end{abstract}

\section{Introduction}

Perovskite solar cells have developed very rapidly over the last several years and could be in considerable demand for various applications in the future photovoltaic market. ${ }^{1-6}$ Numerous scientific research professionals have accelerated increases in power conversion efficiency (PCE) of perovskite solar cells, and at present, the certified world record for a $\mathrm{PCE}$ is $22.1 \% .^{7} \mathrm{As}$ a light absorption layer, $\mathrm{APbX}_{3}\left(\mathrm{~A}=\mathrm{CH}_{3} \mathrm{NH}_{3},\left(\mathrm{NH}_{2}\right)_{2} \mathrm{CH}_{2}\right.$ or Cs, and $\mathrm{X}=\mathrm{I}, \mathrm{Br}$, or $\mathrm{Cl}$ ) is considered as the most promising replacement for silicon solar cells; $\mathrm{APbX}_{3}$ has outstanding properties such as strong light absorption, weakly bound excitons, long-range charge-carrier diffusion, and apparent tolerance to defects. ${ }^{8-10}$

A state-of-the-art photovoltaic solar cell (PSC) is prepared in a conventional n-i-p device configuration consisting of an n-type oxide semiconductor capped with a perovskite absorber and a hole-transport layer (HTL). The electron transfer layer (ETL) of

School of Materials Science and Engineering, Jiangsu Collaborative Innovation Center of Photovoltaic Science and Engineering, Jiangsu Province Cultivation Base for State Key Laboratory of Photovoltaic Science and Technology, Changzhou University, Changzhou 213164, Jiangsu, China.E-mail: dingjn@cczu.edu.cn; nyyuan@cczu.edu. cn

$\dagger$ Electronic supplementary information (ESI) available. See DOI: 10.1039/c8ra01571f
PSCs plays important roles in extracting electrons and blocking holes from perovskite. Metal oxide materials such as $\mathrm{TiO}_{2}, \mathrm{ZnO}$, and $\mathrm{SnO}_{2}$ are widely used in most studies aimed at achieving high efficiency because of their environmentally friendly nature, wide band gap, high electron mobility, and good stability. ${ }^{\mathbf{1 1 - 1 4}}$ A large number of PSCs based on $\mathrm{TiO}_{2}$ require a high-temperature sintering process for their crystallization or removal of the dispersion medium. ${ }^{8-10,15}$ However, $\mathrm{TiO}_{2}, \mathrm{ZnO}$, and $\mathrm{SnO}_{2}$ ETLs obtained using high-temperature treatment cannot be applied to flexible perovskite solar cells. Recently, methods have been developed for fabricating low-temperature processable $\mathrm{TiO}_{2}$ ETLs for planar PSCs, such as atomic layer deposition ${ }^{\mathbf{1 6}}$ and magnetron sputtering. ${ }^{17}$ Compared to vacuum methods, solution-based techniques are generally more cost-effective and scalable and can be used to achieve roll-to-roll process-ability. Therefore, it is imperative to develop effective methods that can restriction migration, improve electron mobility of an ETL, and reduce trap-state density within the perovskite material, thereby eliminating hysteresis and improving the efficiency of PSCs. However, perovskite materials such as $\mathrm{CH}_{3} \mathrm{NH}_{3} \mathrm{PbI}_{3}$ and $\mathrm{CH}\left(\mathrm{NH}_{2}\right)_{2} \mathrm{PbI}_{3}$ are mostly used for PSCs, and these materials practically need annealing for 10-60 min to form the black crystalline photoactive layer. ${ }^{18-23}$ Annealing process is not convenient for mass production because it requires additional equipment and increases energy consumption. One method to address this problem is to employ annealing-free processing, ${ }^{15}$ 
which can save energy and facilitate industrial production. Herein, we propose a facile strategy to prepare a highly efficient perovskite solar cell via room-temperature solution processing. $\mathrm{TiO}_{2}$ films are fabricated by spin coating a colloidal solution of anatase $\mathrm{TiO}_{2}$ nanocrystallines (NCs) prepared via a low-temperature sol-gel method on a substrate. Considering improved performance of the film, we employed niobium ethoxide as a precursor additive. $\mathrm{Nb}_{2} \mathrm{O}_{5}$ is considered a better ETL for a perovskite solar cell due to its higher carrier mobility and conduction band edge position. Here, niobium ethoxide is introduced into the $\mathrm{TiO}_{2}$ dispersion as an aid dispersant. Niobium ethoxide facilitates spontaneous coalescence of the $\mathrm{TiO}_{2} \mathrm{NCs}$, thereby forming a stable dispersion. The stable dispersion is spin-coated onto the conductive base film without annealing; only ultraviolet (UV) treatment for $15 \mathrm{~min}$ yields a uniform and dense $\mathrm{Nb}_{2} \mathrm{O}_{5}-\mathrm{TiO}_{2}$ layer. It is expected that the $\mathrm{Nb}_{2} \mathrm{O}_{5}$ formed in situ would passivate the grain boundary of the $\mathrm{TiO}_{2}$ NCs, and further form a dense and uniform film. The exceptional performance of the layer is attributed to the excellent optical and electronic properties of the $\mathrm{Nb}_{2} \mathrm{O}_{5}-\mathrm{TiO}_{2}$ material, such as a smooth surface and high electron mobility; these properties make the material a better growth platform for a high-quality perovskite absorber layer. In addition, $\mathrm{MAPbI}_{3}$ films are deposited as a light absorption layer via one-step spin-coating by a simple annealing-free process.

\section{Experimental section}

\subsection{Materials}

4-tert-Butylpyridine ( $t$-BP), Li-bis-(trifluoromethanesulfonyl) imide (Li-TFSI), $\mathrm{PbI}_{2}$ (99.9985\%), niobium ethoxide (99.999\%), dimethylacetamide (DMAc) and $N$-methyl-2-pyrrolidone (NMP) were ordered from Alfa Aesar; the methylammonium iodide (MAI) (99.5\%), and 2,2',7,7'-tetrakis[ $N, N$-di(4-methoxyphenyl) amino]-9,9'-spiro-bifluorene (spiro-OMeTAD) (99.8\%) were purchased from Xi'an p-OLED Technology Corp. Titanium tetrachloride $\left(\mathrm{TiCl}_{4}\right.$, anhydrous, $\left.99.5 \%\right)$ and chlorobenzene (anhydrous, 99.9\%) were purchased from Aldrich (USA). All solvents were used without any further purification.

\subsection{Synthesis of $\mathrm{TiO}_{2} \mathrm{NCs}$ and preparation of $\mathrm{TiO}_{2}$ dispersion with niobium ethoxide}

$\mathrm{TiO}_{2}$ NCs were synthesized by a non-hydrolytic sol-gel reaction according to a modified procedure. ${ }^{24}$ The resulting precipitates were washed by adding excess ethanol and diethyl ether and purified by centrifugation at $3000 \mathrm{rpm}$ for $5 \mathrm{~min}$. This washing procedure was repeated thrice. To obtain the $\mathrm{TiO}_{2}$ colloidal solution $\left(\sim 5 \mathrm{mg} \mathrm{mL}^{-1}\right)$, the washed $\mathrm{TiO}_{2}$ NCs were dispersed into anhydrous methanol, and ultrasonic treatment was carried out for several hours. To obtain a niobium ethoxide/ $/ \mathrm{TiO}_{2}$ mixed precursor suspension for spin coating, the purified $\mathrm{TiO}_{2} \mathrm{NCs}\left(5 \mathrm{mg} \mathrm{mL}^{-1}\right)$ were re-dispersed in ethanol at the desired niobium ethoxide concentration. $\mathrm{Nb}_{2} \mathrm{O}_{5}-\mathrm{TiO}_{2}$ ETLs were fabricated by spin-coating at $3000 \mathrm{rpm}$ under ambient conditions, and the films were free from annealing. The samples were treated again with UV-ozone for 15 min before perovskite deposition.

\subsection{Device fabrication}

Pre-patterned transparent conducting oxide substrates were sequentially cleaned using ethanol, acetone, isopropanol, and ethanol separately in an ultrasonic bath for $20 \mathrm{~min}$ each and then dried under flowing nitrogen. Fluorine-doped tin oxide (FTO) substrates underwent UV-ozone treatment (Model UV-03 $\mathrm{UVO}_{3}$ cleaner) for $15 \mathrm{~min}$ before they were used for spin-coating ETLs.

A highly dispersed solution of $\mathrm{TiO}_{2} \mathrm{NCs}$ and $\mathrm{TiO}_{2}$ NCs with niobium ethoxide in ethanol were dropped onto substrates and immediately spin-coated at a speed of $3000 \mathrm{rpm}$ for $30 \mathrm{~s}$. The samples again underwent UV-ozone treatment for $15 \mathrm{~min}$ before perovskite deposition. Then, the $\mathrm{TiO}_{2}\left(\mathrm{Nb}_{2} \mathrm{O}_{5}-\mathrm{TiO}_{2}\right)$ coated substrates were transferred immediately to a nitrogenfilled glovebox for the deposition of perovskite films.

A $\mathrm{MAPbI}_{3}$ solution was prepared according to an annealingfree process reported by Fang et al. ${ }^{15}$ The $\mathrm{MAPbI}_{3}$ precursor solution (1.2 M) was prepared using a mixed solvent of DMAc and NMP in a volume ratio of $5: 1$. Perovskite films were deposited onto the $\mathrm{TiO}_{2}$ or $\mathrm{Nb}_{2} \mathrm{O}_{5}-\mathrm{TiO}_{2}$ substrates according to a two-step spin-coating procedure. In the first step, spin coating was carried out at $1000 \mathrm{rpm}$ for $20 \mathrm{~s}$ with an acceleration of $200 \mathrm{rpm} \mathrm{s}^{-1}$. In the second step, spin coating was carried out at $5000 \mathrm{rpm}$ for $45 \mathrm{~s}$ with an acceleration of $1000 \mathrm{rpm} \mathrm{s}^{-1}$. During the second step, chlorobenzene was dropped onto the spinning substrate at $35 \mathrm{~s}$ before the end of the procedure. At the end of the second step, a dark perovskite film was directly formed. A spiro-OMeTAD HTL was prepared according to a process reported by Yang et al. ${ }^{25}$ The HTL was fabricated as follows:

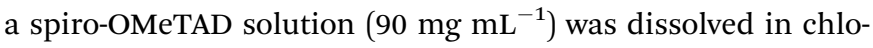
robenzene using $36 \mu \mathrm{L}$ 4-tert-butylpyridine and $22 \mu \mathrm{L}$ lithium bis(trifluoromethylsulfonyl)imide $\left(\begin{array}{llll}520 & \left.\mathrm{mg} \mathrm{mL}^{-1}\right)\end{array}\right.$ as the dopants in acetonitrile. The spiro-OMeTAD solution was spincoated onto the perovskite films at $3000 \mathrm{rpm}$ for $30 \mathrm{~s}$. Finally, an $80 \mathrm{~nm}$ thick gold coating was deposited using a thermal evaporator.

\subsection{Characterization}

Morphologies of the $\mathrm{TiO}_{2}$ films were characterized by fieldemission scanning electron microscopy (FESEM, Zeiss Supra $55)$. The $\zeta$-potential of the $\mathrm{TiO}_{2}$ NCs with different concentrations of niobium ethoxide was characterized by using a size analyzer (Zetasizer Nano ZS ZEN3600 instrument, Malvern Instruments) at room temperature with a $633 \mathrm{~nm}$ laser. The UVvis transilluminator spectra of the samples were recorded on a spectrophotometer (UV5800). High-resolution transmission electron microscopy (HR-TEM) was carried out using an electron microscope (JEM-2100, JEOL Ltd., Japan). The root-meansquare (RMS) roughness and topography images of the films were obtained via atomic force microscopy (AFM, Veeco Dimension V). The quality and crystalline structure of the samples were confirmed by $\theta-2 \theta$ X-ray diffraction (XRD) using an X-ray diffractometer (D/max $2500 \mathrm{PC}$ ) with a $\mathrm{Cu} \mathrm{K} \alpha$ radiation source. A photoluminescence (PL) system (DeltaFlex, Horiba Ltd.) was used to measure the time-resolved PL (TRPL) decay. Photovoltaic performance of the solar cells was measured using 
a multisource meter (Model 2400, Keithley, Cleveland, OH, USA) under one sun (AM 1.5G, $100 \mathrm{~mW} \mathrm{~cm}^{-2}$ ) illumination, which was achieved by using a solar simulator (500 W Xe lamp) (XES40S1, San-Ei Electric Co., Ltd., Japan) as the light source. The device area of $0.07 \mathrm{~cm}^{2}$ was defined by a metal mask. All devices were scanned with a reverse and forward under standard test procedure at a scan rate of $0.2 \mathrm{~V} \mathrm{~s}^{-1}$. X-Ray photoelectron spectroscopy (XPS) was performed on a photoelectron spectrometer (ESCALAB 250Xi, Thermo Fisher Scientific).

\section{Results and discussion}

\subsection{Characterization of $\mathrm{TiO}_{2}$ and $\mathrm{Nb}_{2} \mathrm{O}_{5}-\mathrm{TiO}_{2}$ films}

In the spin-coating process, a stably distributed precursor solution of $\mathrm{TiO}_{2}$ NCs in solution is a prerequisite to form uniform and void-free $\mathrm{TiO}_{2}$ thin films. The niobium ethoxidecapped $\mathrm{TiO}_{2}$ NCs have a uniform dispersion in ethanol, are stable for months, and have better anti-settleability properties (Fig. S1 $\dagger$ ). The $\zeta$-potential is an important factor reflecting colloid stability. The $\zeta$-potential was measured, and the results are shown in Fig. 1. The figure indicates that the $\zeta$-potential value for $\mathrm{TiO}_{2}$ is $16.3 \mathrm{mV}$. The $\zeta$-potential increases with the addition of niobium ethoxide. It demonstrated that the niobium ethoxide plays an important role in the dispersion of $\mathrm{TiO}_{2}$ NCs. Powder XRD measurements of a $\mathrm{TiO}_{2}$ sample revealed typical diffraction peaks of anatase $\mathrm{TiO}_{2}$ (Fig. 2a). The diffraction peaks centered at 25.063, 37.682, 47.882, 54.119, 62.418, and 75.029 are assigned to (101), (004), (200), (105), (204), (116), and (215) diffractions, respectively. This result confirms that the as-synthesized $\mathrm{TiO}_{2}$ NCs are assigned to the anatase crystal structure (PDF no. 21-1272). Scherrer peak width analysis $^{\mathbf{2 6}}$ revealed that the average size of the nanocrystalline domains is approximately $8.8 \mathrm{~nm}$. To gain further insights into the nanoscale morphology and nanocrystal structures, the morphology of as-synthesized $\mathrm{TiO}_{2}$ NCs was investigated using the HR-TEM images. The HR-TEM images (Fig. S2a $\dagger$ ) revealed that the $\mathrm{TiO}_{2} \mathrm{NCs}$ are around 5-10 nm in diameter, which is consistent with the value obtained by Scherrer peak width

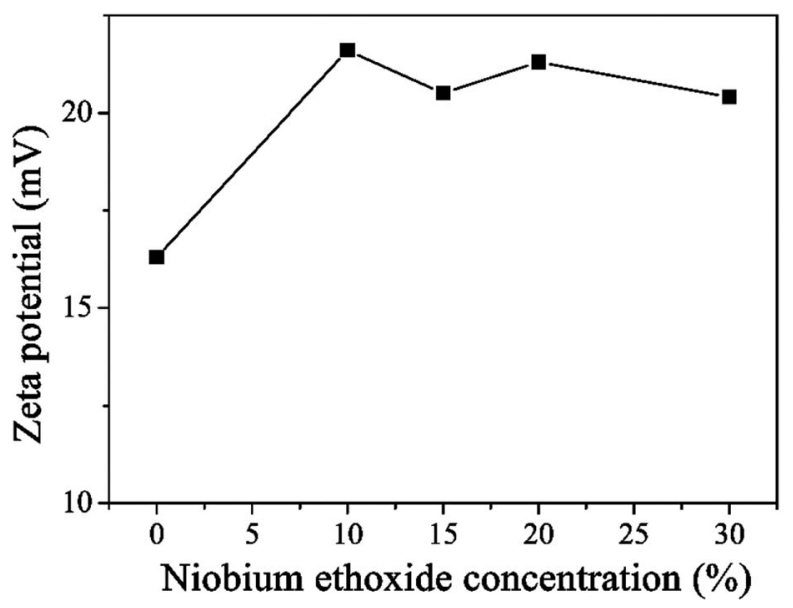

Fig. 1 The zeta potential of $\mathrm{TiO}_{2} \mathrm{NCs}$ with different concentration of niobium ethoxide. analysis. In addition, the selected area electron diffraction pattern for the $\mathrm{TiO}_{2}$ NCs (Fig. S2b $\dagger$ ) confirms the high crystallinity of the $\mathrm{TiO}_{2}$ NCs.

Fig. 2b shows the optical transmission spectra of $\mathrm{TiO}_{2}$ and $\mathrm{Nb}_{2} \mathrm{O}_{5}-\mathrm{TiO}_{2}$. Both the materials show excellent transmittance in the wavelength range of 400-800 $\mathrm{nm}$. The resultant ETLs coated on the FTO glass substrates shows good optical transparency and higher transmittance than the bare FTO glass, with the transmittance being greater than $80 \%$ in the entire visible region. The high transparency of the $\mathrm{Nb}_{2} \mathrm{O}_{5}-\mathrm{TiO}_{2}$ ETLs is very conducive to the light absorption of the perovskite layer and improves light harvesting. No apparent difference was found between the transmittances of different $\mathrm{Nb}_{2} \mathrm{O}_{5}-\mathrm{TiO}_{2}$ films deposited on the FTO substrates.

The composition and bonding type of the $\mathrm{Nb}_{2} \mathrm{O}_{5}-\mathrm{TiO}_{2}$ film were measured using XPS. A typical XPS spectra of $\mathrm{Nb}_{2} \mathrm{O}_{5}-\mathrm{TiO}_{2}$ is shown in Fig. 3a. Clearly, the $\mathrm{O}, \mathrm{Ti}$, and $\mathrm{Nb}$ peaks are located at $\sim 530.59, \sim 458.99$, and $\sim 207.51 \mathrm{eV}$, respectively. The highresolution Ti 2 p (Fig. 3 b) spectrum reveals two different peaks located at 459.04 and $464.69 \mathrm{eV}$, which correspond to $\mathrm{Ti} 2 \mathrm{p}^{3 / 2}$ and Ti $2 \mathrm{p}^{1 / 2}$, respectively; accordingly, a spin-orbit coupling of $5.65 \mathrm{eV}$ is obtained, which is the signature of $\mathrm{Ti}^{4+}$. As shown in the $\mathrm{Nb} 3 \mathrm{~d}$ core level spectra (Fig. $3 \mathrm{c}$ ), $\mathrm{Nb} 3 \mathrm{~d}^{5 / 2}$ and $\mathrm{Nb} 3 \mathrm{~d}^{3 / 2}$ peaks are located at 207.54 and $210.20 \mathrm{eV}$, respectively, indicating the presence of five-valent niobium in the deposited films. ${ }^{27}$ The main binding energy of $530.3 \mathrm{eV}$ is attributed to $\mathrm{O}$ 1s (Fig. 3d) which indicates the $\mathrm{O}^{2-}$ state in $\mathrm{TiO}_{2}$ and the peak at the higher binding energy of $531.4 \mathrm{eV}$ is attributed to surface oxygen-group absorbance or hydroxyl groups. ${ }^{28-31}$

Fig. $4 \mathrm{a}$ and b show the top-view SEM images of the $\mathrm{TiO}_{2}$ and $\mathrm{Nb}_{2} \mathrm{O}_{5}-\mathrm{TiO}_{2}$ films. The $\mathrm{Nb}_{2} \mathrm{O}_{5}-\mathrm{TiO}_{2}$ film is uniform and dense and shows no apparent pinholes, indicating the high quality of the film. The surface morphology of the $\mathrm{Nb}_{2} \mathrm{O}_{5}-\mathrm{TiO}_{2}$ film is not like to that of the pristine $\mathrm{TiO}_{2}$ film. The results of simultaneous energy-dispersive spectroscopy (EDS) of the $\mathrm{Nb}_{2} \mathrm{O}_{5}-\mathrm{TiO}_{2}$ film are shown in Fig. S3. $\uparrow$ When excess niobium ethoxide $30 \%$ and $40 \%$ ) is added, the surface morphology indicates the formation of a porous surface with a large number of pinholes, directly causing a deterioration in the quality of the thin film (Fig. S4 $\dagger$ ). Fig. $4 \mathrm{c}$ and $\mathrm{d}$ shows the AFM height images of the $\mathrm{TiO}_{2}$ and $\mathrm{Nb}_{2} \mathrm{O}_{5}-\mathrm{TiO}_{2}$ films. The RMS roughness decreased from 13.8 to $10.5 \mathrm{~nm}$ because of the introduction of $\mathrm{Nb}_{2} \mathrm{O}_{5}$, indicating that the $\mathrm{Nb}_{2} \mathrm{O}_{5}-\mathrm{TiO}_{2}$ films have flat surfaces. A smooth surface is essential for growing high-quality perovskite films, reducing surface defect trap interfaces with ETLs and HTLs, and enhancing charge extraction at the interface between the ETL and the perovskite layer. ${ }^{32-34}$

To investigate the effect of introducing $\mathrm{Nb}_{2} \mathrm{O}_{5}$ on the electrical properties, the electron mobility was studied by the space charge limited current (SCLC) method using an electron-only device structure. The sample structure used for this measurement was $\mathrm{FTO} / \mathrm{PCBM} / \mathrm{TiO}_{2}\left(15 \% \mathrm{Nb}_{2} \mathrm{O}_{5}-\mathrm{TiO}_{2}\right) / \mathrm{PCBM} / \mathrm{Ag}$. The details are shown in the ESI. $\dagger$ Fig. S5 $\dagger$ shows the current density-voltage $(J-V)$ curves for the $\mathrm{TiO}_{2}$ and $\mathrm{Nb}_{2} \mathrm{O}_{5}-\mathrm{TiO}_{2}$ films fitted using the Mott-Gurney law. ${ }^{34,35}$ It's apparent that the electron mobility of the ETL film increases considerably because of the introduction of $\mathrm{Nb}_{2} \mathrm{O}_{5}$. The electron mobility 

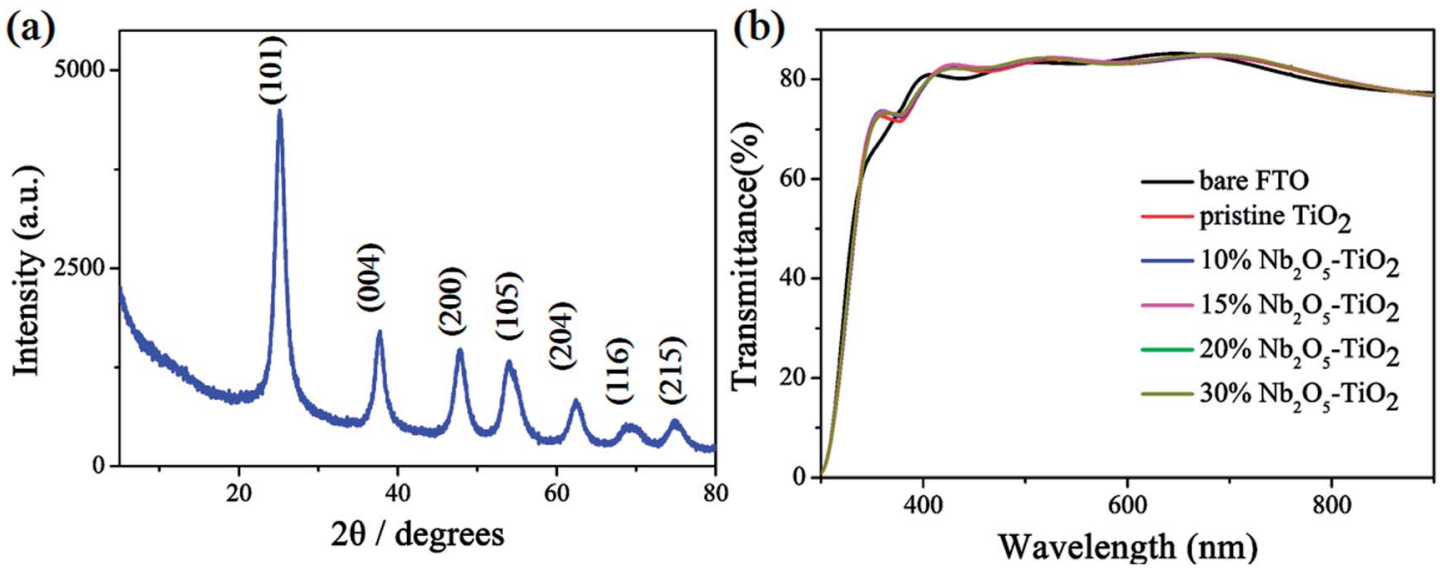

Fig. 2 (a) Powder X-ray diffraction pattern of $\mathrm{TiO}_{2} \mathrm{NCs}$. (b) Transmittance spectra of bare FTO, pristine $\mathrm{TiO}_{2}$, and $\mathrm{Nb}_{2} \mathrm{O}_{5}-\mathrm{TiO}_{2}$ with different niobium ethoxide contents.

increases from $7.09 \times 10^{-4}$ to $1.14 \times 10^{-3} \mathrm{~cm}^{2} \mathrm{~V}^{-1} \mathrm{~s}^{-1}$, which is very close to previous reports that $\mathrm{TiO}_{2}$ modified craft with annealing process. ${ }^{36}$

\subsection{Photovoltaic performance}

The above measurements show that the quality of the $\mathrm{TiO}_{2} \mathrm{NCs}$ film improves considerably because of the introduction of $\mathrm{Nb}_{2} \mathrm{O}_{5} ;$ e.g., the film has a smoother surface and enhanced electron mobility. Next, PSCs were designed and fabricated using the $\mathrm{TiO}_{2}$ and $\mathrm{Nb}_{2} \mathrm{O}_{5}-\mathrm{TiO}_{2}$ ETLs. Fig. S6 $\dagger$ shows the detailed device structure, in which FTO is employed as the anode, the $\mathrm{TiO}_{2}$ or $\mathrm{Nb}_{2} \mathrm{O}_{5}-\mathrm{TiO}_{2}$ film as the ETL, MAPbI 3 as the absorber layer, spiro-OMeTAD as the HTL, and a gold layer as the cathode. A cross-sectional SEM image of the completed device architecture is shown in Fig. S7.† The smooth morphology of the $\mathrm{Nb}_{2} \mathrm{O}_{5}-\mathrm{TiO}_{2}$ films is beneficial for forming
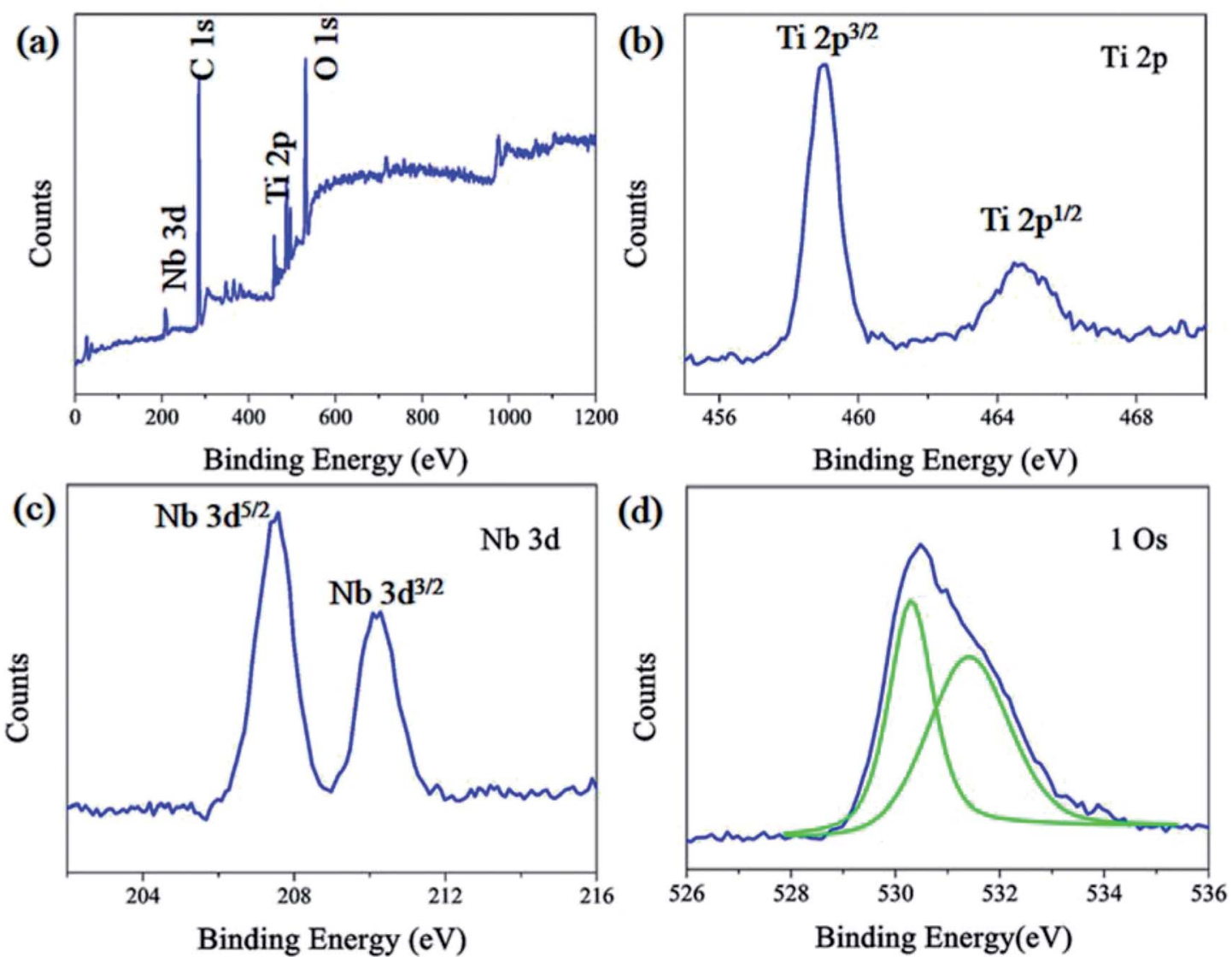

Fig. 3 (a) Typical XPS survey of $\mathrm{Nb}_{2} \mathrm{O}_{5}-\mathrm{TiO}_{2}$ film. High-resolution XPS (b) $\mathrm{Ti} 2 \mathrm{p}$, (c) $\mathrm{Nb} 3 \mathrm{~d}$, and (d) $\mathrm{O} 1 \mathrm{~s}$ peaks of the $\mathrm{Nb}_{2} \mathrm{O}_{5}-\mathrm{TiO}_{2}$ film deposited on a glass substrate. 

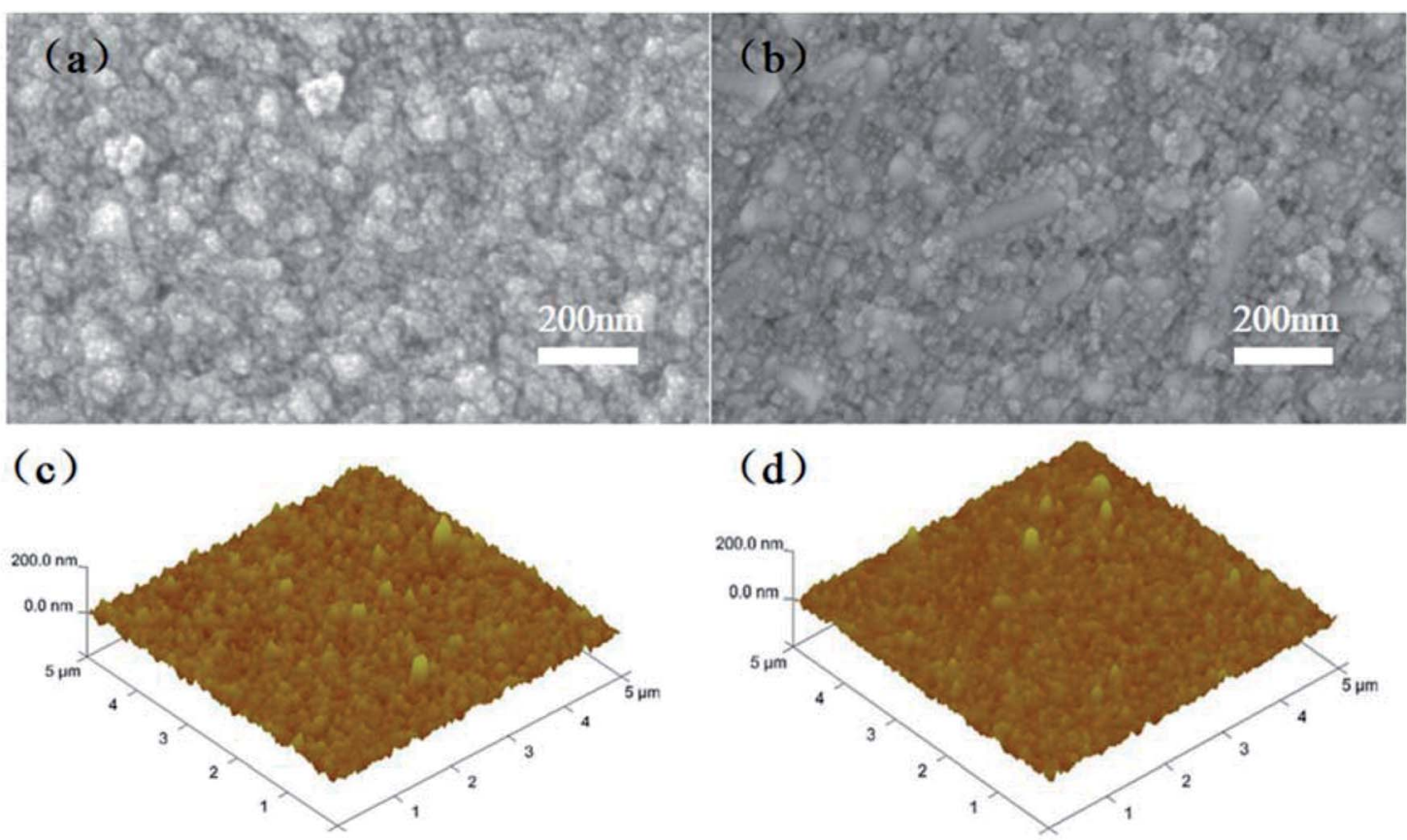

Fig. 4 Top-view SEM images of (a) $\mathrm{TiO}_{2}$ and (b) $\mathrm{Nb}_{2} \mathrm{O}_{5}-\mathrm{TiO}_{2}$ films coated on $\mathrm{FTO}$ substrates. AFM height images of the (c) $\mathrm{TiO}_{2}$ and (d) $\mathrm{Nb}_{2} \mathrm{O}_{5}-$ $\mathrm{TiO}_{2}$ films

highly crystalline and compact perovskite films. Fig. S8 † shows the top-view SEM images of the perovskite film, which exhibits smooth surfaces, big crystalline size, and good coverage. Table $\mathrm{S} 1 \uparrow$ lists the device performance optimized as a function of the $\mathrm{Nb}_{2} \mathrm{O}_{5}$ content; the key $J-V$ parameters are summarized in ESI. $\dagger$ It appears that the PCE increased from $13.47 \%$ to $15.25 \%$. It is apparent that at the optimum $\mathrm{Nb}_{2} \mathrm{O}_{5}$ content, the device performance reaches over $15 \%$. The corresponding photovoltaic parameters for the champion cells are summarized in Table 1. The PSCs based on $\mathrm{TiO}_{2}$ ETLs have a short-circuit current density $\left(J_{\mathrm{sc}}\right)$ of $19.55 \mathrm{~mA} \mathrm{~cm}{ }^{-2}$, an open circuit voltage $\left(V_{\mathrm{oc}}\right)$ of $0.99 \mathrm{~V}$, a fill factor (FF) of 0.698 , and a PCE of $13.47 \%$. Compared to the $\mathrm{TiO}_{2}$ ETL-based PSC, the $\mathrm{Nb}_{2} \mathrm{O}_{5}-\mathrm{TiO}_{2}$ ETL-based PSC has enhanced parameter values: $J_{\mathrm{sc}}$ is $20.49 \mathrm{~mA} \mathrm{~cm}{ }^{-2}, V_{\mathrm{oc}}$ is $1.04 \mathrm{~V}$, FF is 0.716 , and the PCE is $15.25 \%$, which is the best efficiency achieved in this study. Compared to the $\mathrm{TiO}_{2}$ ETL-based device, all the key $J-V$ parameters of the $\mathrm{Nb}_{2} \mathrm{O}_{5}-\mathrm{TiO}_{2}$ ETL-based device are considerably better. Fig. 5 a shows the $J-V$ curves for the champion devices based on both $\mathrm{TiO}_{2}$ and $\mathrm{Nb}_{2} \mathrm{O}_{5}-\mathrm{TiO}_{2}$ ETLS measured in the reverse and forward scan directions. Compared to the control device, the photovoltaic performance of these champion devices is considerably better; the larger $J_{\mathrm{sc}}$ and FF

Table 1 Key parameters of champion PSCs based on pristine $\mathrm{TiO}_{2}$ and $\mathrm{Nb}_{2} \mathrm{O}_{5}-\mathrm{TiO}_{2} \mathrm{ETLS}$

\begin{tabular}{|c|c|c|c|c|c|}
\hline & Scan direction & $V_{\mathrm{oc}}(\mathrm{V})$ & $J_{\mathrm{sc}}\left(\mathrm{mA} \mathrm{cm} \mathrm{cm}^{-2}\right)$ & $\mathrm{FF}$ & PCE $(\%)$ \\
\hline \multirow[t]{2}{*}{$\mathrm{Nb}_{2} \mathrm{O}_{5}-\mathrm{TiO}_{2}$} & Reverse & 1.04 & 20.49 & 0.716 & $15.25 \%$ \\
\hline & Forward & 1.02 & 20.47 & 0.678 & $14.17 \%$ \\
\hline \multirow{2}{*}{$\mathrm{TiO}_{2}$} & Reverse & 0.99 & 19.55 & 0.698 & $13.47 \%$ \\
\hline & Forward & 0.93 & 19.76 & 0.664 & $12.17 \%$ \\
\hline
\end{tabular}

are attributed to the improved electron mobility and better hole blocking effect of the $\mathrm{Nb}_{2} \mathrm{O}_{5}-\mathrm{TiO}_{2}$ ETL, and the high $V_{\text {oc }}$ may be due to the reduced charge recombination and improved electron extraction. ${ }^{37-39}$ Fig. 5b shows the incident photon-tocurrent efficiency spectra for various ETLs. The integrated current density value for the pristine $\mathrm{TiO}_{2}$-based cell is $18.92 \mathrm{~mA}$ $\mathrm{cm}^{-2}$, and it increases to $19.50 \mathrm{~mA} \mathrm{~cm}{ }^{-2}$ for the $\mathrm{Nb}_{2} \mathrm{O}_{5}-\mathrm{TiO}_{2}$ based device; that value is in good agreement with the $J-V$ measurement value. Performance statistics for 30 individual cells with $\mathrm{TiO}_{2}$ and $\mathrm{Nb}_{2} \mathrm{O}_{5}-\mathrm{TiO}_{2}$ ETLs are shown in Fig. 6 . Clearly, PCEs show a narrower distribution with a smaller standard deviation for the $\mathrm{Nb}_{2} \mathrm{O}_{5}-\mathrm{TiO}_{2}$-based cells, indicating good reproducibility.

\subsection{Recombination}

To gain insight into the electron extraction and transport mechanism, the steady-state PL and TRPL were measured for the perovskite absorber layer deposited on both the ETL-based substrates. Fig. 7a shows that the spectral peak for the FTO/ perovskite sample at $766 \mathrm{~nm}$ apparently has the highest PL intensity, indicating serious recombination occurring in the sample. The $\mathrm{FTO} / \mathrm{Nb}_{2} \mathrm{O}_{5}-\mathrm{TiO}_{2} /$ perovskite sample has the lowest $\mathrm{PL}$ intensity, even lower than that of the $\mathrm{FTO} / \mathrm{TiO}_{2} /$ perovskite sample. Interestingly, compared to the PL peak for the control samples, the peak for the $\mathrm{FTO} / \mathrm{Nb}_{2} \mathrm{O}_{5}-\mathrm{TiO}_{2} /$ perovskite film exhibits a considerable blue-shift. ${ }^{40}$ This suggests that $\mathrm{Nb}_{2} \mathrm{O}_{5}-$ $\mathrm{TiO}_{2}$ substrate is favorable to obtain higher-quality perovskite films than the control group. Perovskite with higher crystallinity and considerably less trap density than the corresponding bandgap will decrease (i.e., the conduction band minimum will move down). ${ }^{41}$ Fig. $7 \mathrm{~b}$ shows the time-resolved 

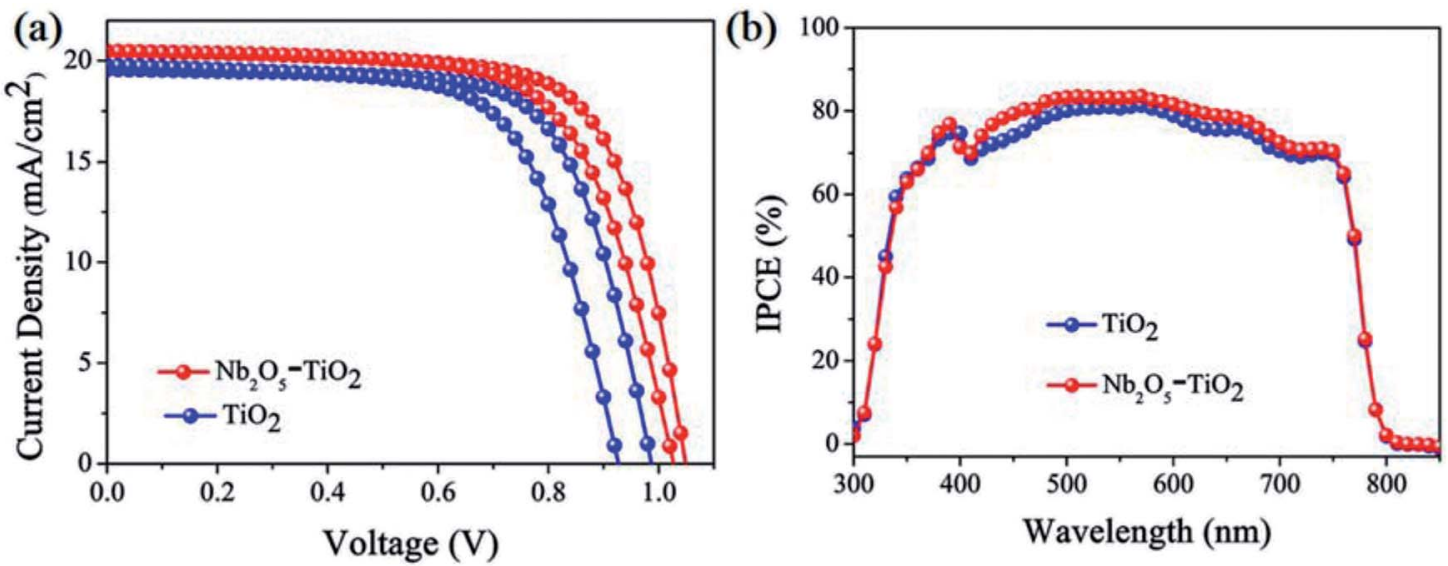

Fig. 5 (a) $J-V$ curves and (b) IPCE spectra of the best-performing PSCs made with $\mathrm{TiO}_{2}$ and $\mathrm{Nb}_{2} \mathrm{O}_{5}-\mathrm{TiO}_{2}$ ETLs on FTO glass.

photoluminescence (TRPL) decay curves obtained to analyze the PL lifetimes of the perovskite films prepared on both the ETLbased substrates. PL decay transients and the corresponding PL lifetimes were obtained by performing fitting using a biexponential decay function, $f(t)=A_{1} \exp \left(-t / \tau_{1}\right)+A_{2} \exp \left(-t / \tau_{2}\right)$, where $\tau_{1}$ is the fast transient component representing the surface properties and $\tau_{2}$ is the slow component resulting from the bulk properties. ${ }^{42,43}$ The fitted parameters for the glass/ perovskite, glass $/ \mathrm{TiO}_{2} /$ perovskite, and glass $/ \mathrm{Nb}_{2} \mathrm{O}_{5}-\mathrm{TiO}_{2} /$ perovskite samples are summarized in Table S2. $\dagger$ For the glass/ $\mathrm{CH}_{3} \mathrm{NH}_{3} \mathrm{PbI}_{3}$ sample, $\tau_{1}$ is $1.05 \mathrm{~ns}(1.89 \%)$ and $\tau_{2}$ is $429.50 \mathrm{~ns}$ (98.11\%), with an amplitude average lifetime of 49.40 ns. For the $\mathrm{TiO}_{2} / \mathrm{CH}_{3} \mathrm{NH}_{3} \mathrm{PbI}_{3}$ sample, $\tau_{1}$ is $1.36 \mathrm{~ns}(2.93 \%)$ and $\tau_{2}$ is $255.33 \mathrm{~ns}(97.07 \%)$, with an amplitude average lifetime of 39.48 ns. For the $\mathrm{Nb}_{2} \mathrm{O}_{5}-\mathrm{TiO}_{2} / \mathrm{CH}_{3} \mathrm{NH}_{3} \mathrm{PbI}_{3}$ sample, $\tau_{1}$ is $0.92 \mathrm{~ns}$ $(11.68 \%)$ and $\tau_{2}$ is $223.58 \mathrm{~ns}(88.32 \%)$, with an average lifetime was $7.60 \mathrm{~ns}$. Therefore, it is apparent that the photon-induced electrons transfer from perovskite to the $\mathrm{Nb}_{2} \mathrm{O}_{5}-\mathrm{TiO}_{2}$ ETL is faster and more effective than that from perovskite to the $\mathrm{TiO}_{2}$ ETL. Thus, the PL characterizations confirm that the large enhancement in the photovoltaic performances of the $\mathrm{Nb}_{2} \mathrm{O}_{5}-$ $\mathrm{TiO}_{2}$ ETL can be attributed to the enhanced charge extraction.

\subsection{Flexible perovskite solar cells}

The totally room-temperature UV process for efficient ETLs is very suitable for fabricating high-performance flexible PSCs. The excellent performance of uniform and dense $\mathrm{Nb}_{2} \mathrm{O}_{5}-\mathrm{TiO}_{2}$ ETLs prompted us to fabricate flexible perovskite solar cells using flexible substrates. $\mathrm{Nb}_{2} \mathrm{O}_{5}-\mathrm{TiO}_{2}$ ETLs were successfully fabricated on indium tin oxide (ITO)/PET substrates, and perovskite, spiro-OMeTAD, and a gold electrode were sequentially deposited using the same methods as those used for the FTO glass-based devices. Fig. 8a shows the $J-V$ curves for the perovskite solar cells fabricated using flexible ITO/PET substrates, and the inset illustrates a photograph of a flexible perovskite solar cell fabricated using flexible ITO/PET substrates. For the flexible device, $J_{\mathrm{sc}}$ is $20.04 \mathrm{~mA} \mathrm{~cm}{ }^{-2}, V_{\mathrm{oc}}$ is $0.99 \mathrm{~V}$, and the FF is 0.69 , giving the best PCE of $13.60 \%$. The PCE is lower than that of the rigid device because of the decreased $J_{\mathrm{sc}}, V_{\mathrm{oc}}$ and FF; the decrease is probably caused by the higher series resistance and lower transmittance of the ITO/PET substrate in the short wavelength spectrum. ${ }^{17}$ Fig. 8 b shows the $J-V$ curves for the flexible device after it is recovered from the given bending radius. The key $J-V$ parameters of the devices are summarized in Table S3. $\dagger$ After the device is bent with $R=10,5$,
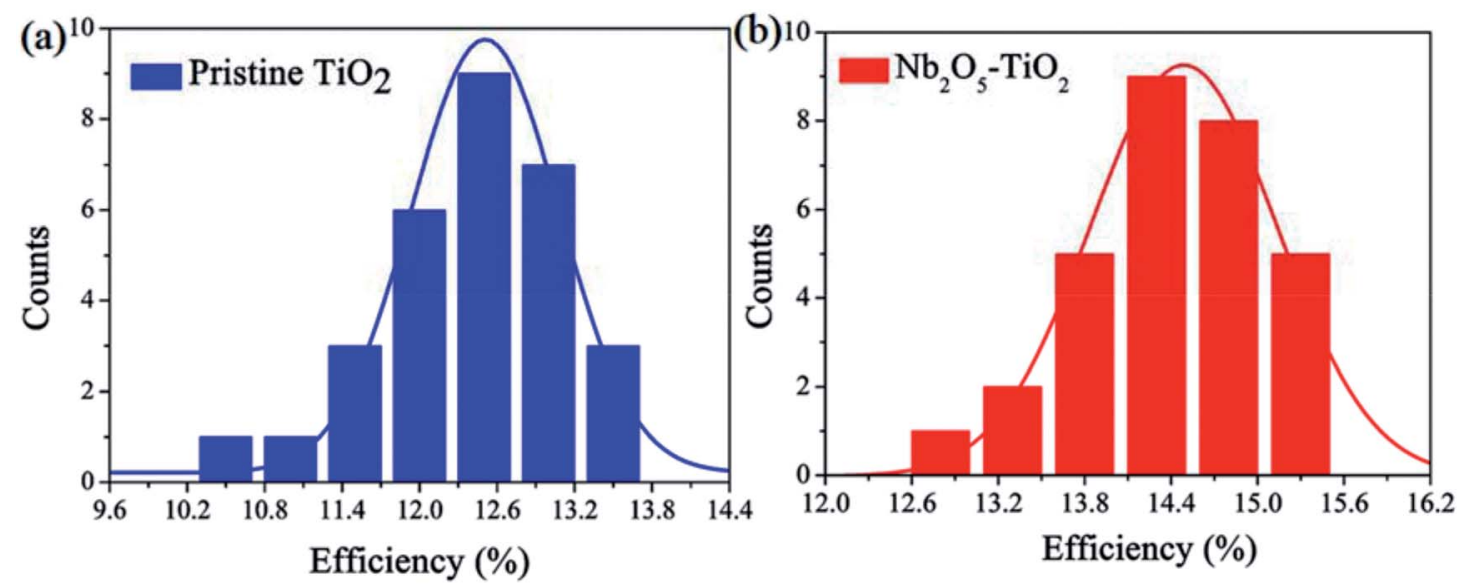

Fig. 6 PCE distribution histogram of PSCs based on $\mathrm{TiO}_{2}$ (a) and $\mathrm{Nb}_{2} \mathrm{O}_{5}-\mathrm{TiO}_{2}$ (b) $\mathrm{ETLs}$. 

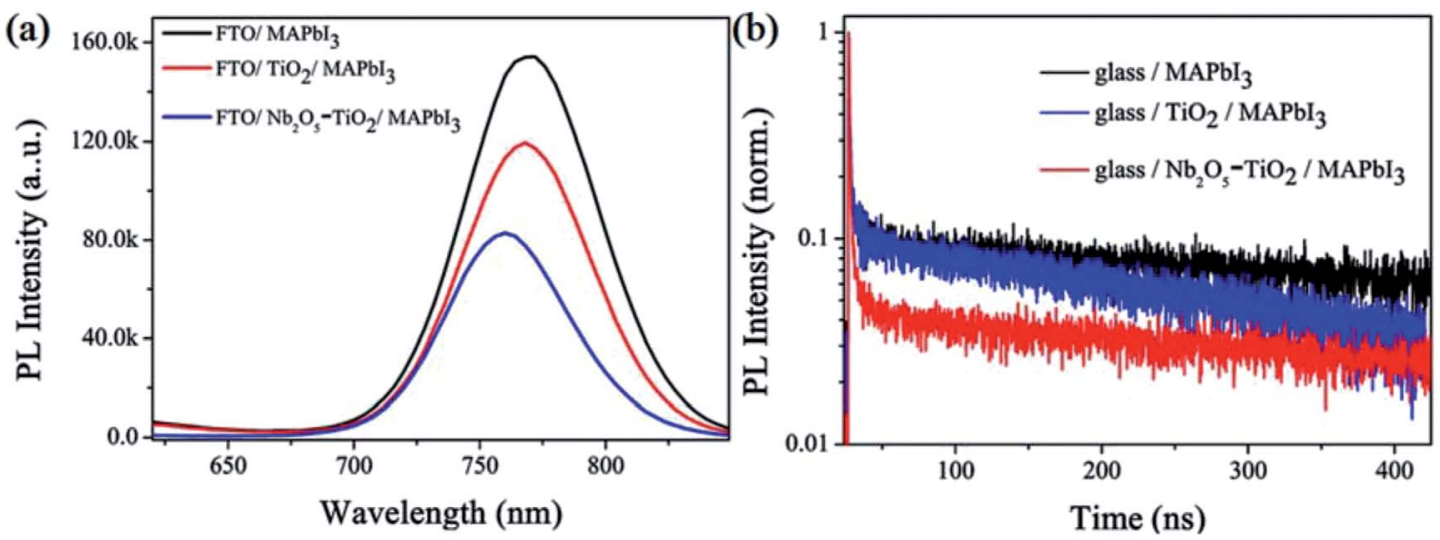

Fig. 7 (a) Steady-state photoluminescence (PL) spectra and (b) normalized time-resolved photoluminescence (TRPL) spectra of pristine perovskite and perovskite layers grown on $\mathrm{TiO}_{2}$ and $\mathrm{Nb}_{2} \mathrm{O}_{5}-\mathrm{TiO}_{2} \mathrm{ETLs}$.
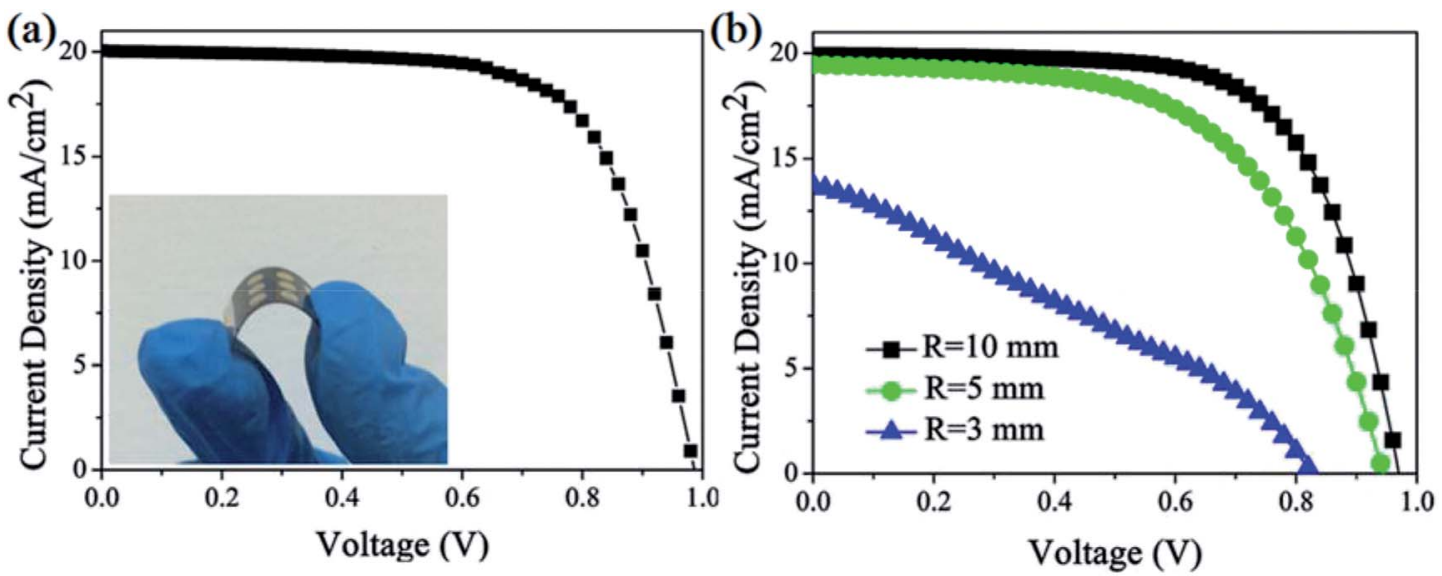

Fig. 8 (a) The $J-V$ curves of best PCE of the perovskite solar cells device using flexible PET/ITO substrates. The inset shows the flexible PSC based on $\mathrm{Nb}_{2} \mathrm{O}_{5}-\mathrm{TiO}_{2}$ ETLs coated on ITO/PET substrate. (b) $\mathrm{J}-V$ curves of the flexible PSCs obtained after recovery from bending at various radius $(R=10,5$, and $3 \mathrm{~mm})$.

and $3 \mathrm{~mm}$, the PCE values degenerate to $13.03 \%, 10.70 \%$, and $3.39 \%$, respectively. As shown in Fig. $8 \mathrm{~b}$, the performance of the flexible device does not show serious degradation when the bending radius is $10 \mathrm{~mm}$. When the bending radius is $3 \mathrm{~mm}$, the brittle ITO breaks ${ }^{\mathbf{4}}$ and the PCE is greatly reduced simultaneously, indicating that the flexible devices show good mechanical stability and the $\mathrm{Nb}_{2} \mathrm{O}_{5}-\mathrm{TiO}_{2}$ ETLs is a promising electron transport material.

\section{Conclusion}

We have demonstrated that $\mathrm{Nb}_{2} \mathrm{O}_{5}-\mathrm{TiO}_{2}$ is an excellent ETL material for perovskite solar cells, with the champion cell showing a considerably higher PCE $(15.25 \%)$ than that of devices based on a pristine $\mathrm{TiO}_{2}$ ETL and that of a rigid substrate $(13.47 \%)$. In the proposed process, niobium ethoxide facilitates the spontaneous coalescence of the $\mathrm{TiO}_{2} \mathrm{NCs}$, thereby forming $\mathrm{Nb}_{2} \mathrm{O}_{5}-\mathrm{TiO}_{2}$ ETL. Our results suggest that lowtemperature solution-processed $\mathrm{Nb}_{2} \mathrm{O}_{5}-\mathrm{TiO}_{2}$ could be a good ETL candidate for producing efficient perovskite solar cells. Our facile strategy is highly suitable for fabricating high- performance flexible PSCs because it does not need a hightemperature process and can easily modify the ETL via the direct addition of a reagent. This approach will pave the way for further advances in flexible PSCs and is feasible for large scale roll-to-roll processing.

\section{Conflicts of interest}

There are no conflicts to declare.

\section{Acknowledgements}

This work was supported by the National Natural Science Foundation of China (Grant No. 51572037, 51335002), the Priority Academic Program Development of Jiangsu Higher Education Institutions and Jiangsu Science and Technology Project (BE2017006-3), the Natural Science Foundation of the Jiangsu Higher Education Institutions of China (Grant No. 14KJA430001). 


\section{References}

1 H. P. Zhou, Q. Chen, G. Li, S. Luo, T.-B. Song, H. -S. Duan, Z. R. Hong, J.-B. You, Y. S. Liu and Y. Yang, Interface engineering of highly efficient perovskite solar cells, Science, 2014, 345(6196), 542-546.

2 X. Li, D. Q. Bi, C. Y. Yi, J.-D. Décoppet, J. S. Luo, S. M. Zakeeruddin, A. Hagfeldt and M. Grätzel, A vacuum flash-assisted solution process for high-efficiency large-area perovskite solar cells, Science, 2016, 353(6294), 58-62.

3 Z. Wang, Z. J. Shi, T. T. Li, Y. H. Chen and W. Huang, Stability of Perovskite Solar Cells: A Prospective on the Substitution of the A Cation and X Anion, Angew. Chem., Int. Ed., 2017, 56(5), 1190-1212.

4 H. Tsai, W. Nie, J. C. Blancon, C. C. Stoumpos, R. Asadpour, B. Harutyunyan, A. J. Neukirch, R. Verduzco, J. J. Crochet, S. Tretiak, L. Pedesseau, J. Even, M. A. Alam, G. Gupta, J. Lou, P. M. Ajayan, M. J. Bedzyk and M. G. Kanatzidis, High-efficiency two-dimensional Ruddlesden-Popper perovskite solar cells, Nature, 2016, 536(7616), 312-316.

5 H. Chen, F. Ye, W. T. Tang, J. J. He, M. S. Yin, Y. B. Wang, F. X. Xie, E. B. Bi, X. D. Yang, M. Grätzel and L. Y. Han, A solvent- and vacuum-free route to large-area perovskite films for efficient solar modules, Nature, 2017, 550(7674), 92-95.

6 X. Zhang, X. D. Ren, B. Liu, R. Munir, X. J. Zhu, Y. Dong, J. B. Li, Y. C. Liu, D.-M. Smilgies, R. P. Li, Z. Yang, T. Q. Niu, X. L. Wang, A. Amassian, K. Zhao and S. Z. Liu, Stable high efficiency two-dimensional perovskite solar cells via cesium doping, Energy Environ. Sci., 2017, 10(10), 2095-2102.

7 National Renewable Energy Laboratory (NREL), Best Research-Cell Efficiencies Chart, 2017, http://www.nrel.gov/ pv/assets/images/efficiency-chart.png.

8 H. Y. Zhang, J. J. Shi, X. Xu, L. F. Zhu, Y. H. Luo, D. M. Li and Q. B. Meng, Mg-doped $\mathrm{TiO}_{2}$ boosts the efficiency of planar perovskite solar cells to exceed $19 \%, J$. Mater. Chem. A, 2016, 4(40), 15383-15389.

9 D. T. Liu, S. B. Li, P. Zhang, Y. F. Wang, R. Zhang, H. Sarvari, F. Wang, J. Wu, Z. M. Wang and Z. D. Chen, Efficient planar heterojunction perovskite solar cells with Li-doped compact $\mathrm{TiO}_{2}$ layer, Nano Energy, 2017, 31, 462-468.

10 A. A. Sutanto, S. Lan, C.-F. Cheng, S. B. Mane, H.-P. Wu, M. Leonardus, M.-Y. Xie, S.-C. Yeh, C.-W. Tseng, C.-T. Chen, E. W.-G. Diau and C.-H. Hung, Solvent-assisted crystallization via a delayed-annealing approach for highly efficient hybrid mesoscopic/planar perovskite solar cells, Sol. Energy Mater. Sol. Cells, 2017, 172, 270-276.

11 K. Wojciechowski, M. Saliba, T. Leijtens, A. Abatea and H. J. Snaith, Sub-150 ${ }^{\circ} \mathrm{C}$ processed meso-superstructured perovskite solar cells with enhanced efficiency, Energy Environ. Sci., 2014, 7(3), 1142-1147.

12 K. Mahmood, B. S. Swain and H. S. Jung, Controlling the Surface Nanostructure of $\mathrm{ZnO}$ and Al-doped $\mathrm{ZnO}$ Thin Films Using Electrostatic Spraying for Their Application in
12\% Efficient Perovskite Solar Cells, Nanoscale, 2014, 6(15), 9127-9138.

13 W. S. Yang, J. H. Noh, N. J. Jeon, Y. C. Kim, S. C. Ryu, J. W. Seo and S. Seok II, High-performance photovoltaic perovskite layers fabricated through intramolecular exchange, Science, 2015, 348(6240), 1234-1237.

14 L. Xiong, M. Qin, C. Chen, J. Wen, G. Yang, Y. Guo, J. Ma, Q. Zhang, P. Qin, S. Z. Li and G. J. Fang, Fully HighTemperature-Processed $\mathrm{SnO}_{2}$ as Blocking Layer and Scaffold for Efficient, Stable, and Hysteresis-Free Mesoporous Perovskite Solar Cells, Adv. Funct. Mater., 2018, 28(10), 1706276.

15 X. Fang, Y. H. Wu, Y. T. Lu, Y. Sun, S. Zhang, J. Zhang, W. H. Zhang, N. Y. Yuan and J. N. Ding, Annealing-free perovskite films based on solvent engineering for efficient solar cells, J. Mater. Chem. C, 2017, 5(4), 842-847.

16 J. P. C. Baena, L. Steier, W. Tress, M. Saliba, S. Neutzner, T. Matsui, F. T. Giordano, J. Jacobsson, A. R. S. Kandada, S. M. Zakeeruddin, A. Petrozza, A. Abate, M. K. Nazeeruddin, M. Grätzel and A. Hagfeldt, Highly efficient planar perovskite solar cells through band alignment engineering, Energy Environ. Sci., 2015, 8(10), 2928-2934.

17 D. Yang, R. X. Yang, J. Zhang, Z. Yang, S. Z. Liu and C. Li, High efficiency flexible perovskite solar cells using superior low temperature $\mathrm{TiO}_{2}$, Energy Environ. Sci., 2015, 8(11), 3208-3214.

18 J. Ma, X. Zheng, H. Lei, W. Ke, C. Chen, Z. Chen, G. Yang and G.-J. Fang, Highly efficient and stable planar perovskite solar cells with large-scale manufacture of e-beam evaporated $\mathrm{SnO}_{2}$ toward commercialization, Solar RRL, 2017, 1(10), 1700118.

19 X. Fang, J. N. Ding, N. Y. Yuan, P. Sun, M. H. Lv, G. Q. Ding and C. Zhu, Graphene quantum dot incorporated perovskite films: passivating grain boundaries and facilitating electron extraction, Phys. Chem. Chem. Phys., 2017, 19(8), 6057-6063.

20 L.-L. Gao, C.-X. Li, C.-J. Li and G.-J. Yang, Large-area highefficiency perovskite solar cells based on perovskite films dried by the multi-flow air knife method in air, J. Mater. Chem. A, 2016, 5(4), 1548-1557.

21 T. Matsui, J.-Y. Seo, M. Saliba, S. M. Zakeeruddin and M. Grätzel, Room-Temperature Formation of Highly Crystalline Multication Perovskites for Efficient, Low-Cost Solar Cells, Adv. Mater., 2017, 29(15), 1606258.

22 X. T. Yin, P. Chen, M. D. Que, Y. L. Xing, W. X. Que, C. M. Niu and J. Y. Shao, Highly Efficient Flexible Perovskite Solar Cells Using Solution-Derived $\mathrm{NiO}_{x}$ Hole Contacts, ACS Nano, 2016, 10(3), 3630-3636.

23 G. Yang, C. Chen, F. Yao, Z. Chen, Q. Zhang, X. Zheng, J. Ma, H. Lei, P. Qin, L. Xiong, W. Ke, G. Li, Y. Yan and G. Fang, Effective Carrier-Concentration Tuning of $\mathrm{SnO}_{2}$ Quantum Dot Electron-Selective Layers for High-Performance Planar Perovskite Solar Cells, Adv. Mater., 2018, 1706023, DOI: 10.1002/adma.201706023.

24 H. Tan, A. Jain, O. Voznyy, X.-Z. Lan, F. P. García de Arquer, J. Z. Fan, R. Quintero-Bermudez, M. J. Yuan, B. Zhang, Y. Zhao, F. Fan, P. Li, L. N. Quan, Y. Zhao, Z.-H. Lu, 
Z. Yang, S. Hoogland and E. H. Sargent, Efficient and stable solution-processed planar perovskite solar cells via contact passivation, Science, 2017, 355(6326), 722-726.

25 D. Yang, R. Yang, X. Ren, X. Zhu, Z. Yang, C. Li and S. Liu, Hysteresis-Suppressed High-Efficiency Flexible Perovskite Solar Cells Using Solid-State Ionic-Liquids for Effective Electron Transport, Adv. Mater., 2016, 28(26), 5206-5213.

26 C. Yang, Mi. Yu, D. Chen, Y. Zhou, W. Wang, Y. Li, T.-C. Lee and D. Yun, An annealing-free aqueous-processed anatase $\mathrm{TiO}_{2}$ compact layer for efficient planar heterojunction perovskite solar cells, Chem. Commun., 2017, 53(79), 10882-10885.

27 J. P. C. Baena, L. Steier, W. Tress, M. Saliba, S. Neutzner, T. Matsui, F. Giordano, T. J. Jacobsson, A. R. S. Kandada, S. M. Zakeeruddin, A. Petrozza, A. Abate, M. K. Nazeeruddin, M. Grätzel and A. Hagfeldt, Highly Efficient Planar Perovskite Solar Cells through Band Alignment Engineering, Energy Environ. Sci., 2015, 8(10), 2928-2934.

28 X. Ling, J. Yuan, D. Liu, Y. Wang, Y. Zhang, S. Chen, H. Wu, F. Jin, F. Wu, G. Shi, X. Tang, J. Zheng, S. Liu, Z. Liu and W. Ma, Room-Temperature Processed $\mathrm{Nb}_{2} \mathrm{O}_{5}$ as the Electron-Transporting Layer for Efficient Planar Perovskite Solar Cells, ACS Appl. Mater. Interfaces, 2017, 9(27), 2318123188.

29 N. Usha, R. Sivakumar, C. Sanjeeviraja and M. Arivanandhan, Niobium Pentoxide $\left(\mathrm{Nb}_{2} \mathrm{O}_{5}\right)$ Thin Films: Rf Power and Substrate Temperature Induced Changes in Physical Properties, Optik, 2015, 126(19), 1945-1950.

30 B.-X. Chen, H.-S. Rao, W.-G. Li, Y.-F. Xu, H.-Y. Chen, D.-B. Kuang and C.-Y. Su, Achieving high-performance planar perovskite solar cell with $\mathrm{Nb}$-doped $\mathrm{TiO}_{2}$ compact layer by enhanced electron injection and efficient charge extraction, J. Mater. Chem. A, 2016, 4(15), 5647-5653.

31 W. Ke, G. Fang, Q. Liu, L. Xiong, P. Qin, H. Tao, J. Wang, H. Lei, B. Li, J. Wan, G. Yang and Y. Yan, Low-Temperature Solution-Processed Tin Oxide as an Alternative Electron Transporting Layer for Efficient Perovskite Solar Cells, J. Am. Chem. Soc., 2015, 137(21), 6730-6733.

32 S. Pisoni, F. Fu, T. Feurer, M. Makha, B. Bissig, S. Nishiwaki, A. N. Tiwari and S. Buecheler, Flexible NIR-transparent perovskite solar cells for all-thin-film tandem photovoltaic devices, J. Mater. Chem. A, 2017, 5(26), 13639-13647.

33 W. Zhang, M. Saliba, D. T. Moore, S. K. Pathak, M. T. Hörantner, T. Stergiopoulos, S. D. Stranks, G. E. Eperon, J. A. Alexander-Webber, A. Abate, A. Sadhanala, S. Yao, Y. Chen, R. H. Friend, L. A. Estroff, U. Wiesner and H. J. Snaith, Ultrasmooth organicinorganic perovskite thin-film formation and crystallization for efficient planar heterojunction solar cells, Nat. Commun., 2015, 6, 6142.

34 A. M. Goodman and A. Rose, Double Extraction of Uniformly Generated Electron-Hole Pairs from Insulators with Noninjecting Contacts, J. Appl. Phys., 1971, 42(7), 2823-2830. 35 C. Goh, R. J. Kline, M. D. McGehee, E. N. Kadnikova and J. M. J. Frechet, Molecular-weight-dependent mobilities in regioregular poly(3-hexyl-thiophene) diodes, Appl. Phys. Lett., 2005, 86(12), 122110.

36 D. Yang, X. Zhou, R. Yang, Y. Zhou, Y. Wei, X.-L. Wang, Can Li, S.-Z. Liu and P. H. Chang Robert, Surface optimization to eliminate hysteresis for record efficiency planar perovskite solar cells, Energy Environ. Sci., 2016, 9(10), 3071-3078.

37 Q. Jiang, Z. Chu, P. Wang, X. Yang, H. Liu, Y. Wang, Z. Yin, J. Wu, X. Zhang and J. You, Planar-Structure Perovskite Solar Cells with Efficiency beyond 21\%, Adv. Mater., 2017, 29(46), 1703852.

38 G. Yang, H. Lei, H. Tao, X. Zheng, J. Ma, Q. Liu, W. Ke, Z. Chen, L. Xiong, P. Qin, Z. Chen, M. Qin, X. Lu, Y. Yan and G. Fang, Reducing Hysteresis and Enhancing Performance of Perovskite Solar Cells Using LowTemperature Processed Y-Doped $\mathrm{SnO}_{2}$ Nanosheets as Electron Selective Layers, Small, 2017, 13(2), 1601769.

39 P. Wang, J. Zhao, J. Liu, L. Wei, Z. Liu, L. Guan and G. Cao, Stabilization of organometal halide perovskite films by $\mathrm{SnO}_{2}$ coating with inactive surface hydroxyl groups on $\mathrm{ZnO}$ nanorods, J. Power Sources, 2017, 339(30), 51-60.

40 Y. Shao, Z. Xiao, C. Bi, Y. Yuan and J. Huang, Origin and elimination of photocurrent hysteresis by fullerene passivation in $\mathrm{CH}_{3} \mathrm{NH}_{3} \mathrm{PbI}_{3}$ planar heterojunction solar cells, Nat. Commun., 2014, 5, 5784.

41 M. Long, T. Zhang, W. Xu, X. Zeng, F. Xie, Q. Li, Z. Chen, F. Zhou, K. S. Wong, K. Yan and J. Xu, Large-Grain Formamidinium $\mathrm{PbI}_{3-x} \mathrm{Br}_{x}$ for High-Performance Perovskite Solar Cells via Intermediate Halide Exchange, Adv. Energy Mater., 2017, 7(12), 1601882.

42 J. W. Lee, H. S. Kimand and N. G. Park, Lewis Acid-Base Adduct Approach for High Efficiency Perovskite Solar Cells, Acc. Chem. Res., 2016, 49(2), 311-319.

43 Q. Dong, Y. Fang, Y. Shao, P. Mulligan, J. Qiu, L. Cao and J. Huang, Electron-hole diffusion lengths $>175 \mu \mathrm{m}$ in solution-grown $\mathrm{CH}_{3} \mathrm{NH}_{3} \mathrm{PbI}_{3}$ single crystals, Science, 2015, 347(6225), 967-970.

44 J. W. Jo, M. Seo, M. Park, J. Kim, J. S. Park, I. K. Han, H. Ahn, J. W. Jung, B.-H. Sohn, M. J. Ko and H. J. Son, Improving Performance and Stability of Flexible PlanarHeterojunction Perovskite Solar Cells Using Polymeric Hole-Transport Material, Adv. Funct. Mater., 2016, 26(25), 4464-4471. 